\title{
Dietary Goat Milk Potential in Prevention of Hypertension in Sedentary Women
}

\author{
Yusni \\ Department of Physiology, Faculty of Medicine, Syiah Kuala University, Indonesia \\ yusnieunsyiah.ac.id
}

\begin{abstract}
There are persistent rumors in Indonesia, including Aceh people that the consumption of goat milk can effect to increases blood pressure (BP) and cause of hypertension, but there is no scientific evidence to support this. This research was conducted to analysis the effect of dietary goat milk on blood pressure and it's relation with serum calcium in sedentary women. This research were randomized clinical trial with randomized double blind design, using 18 sedentary women aged 18-19 years. The treatment was goat's milk $250 \mathrm{ml} / \mathrm{day}$, given at 8:00 to 09:00 pm, for 110 days. The result showed that systolic $(101.11 \pm 3.09$ and $93.33 \pm 1.66$ vs $112.22 \pm 3.23$ and $110 \pm 2.88$ $\mathrm{mmHg})$ and diastolic blood pressure $(70 \pm 2.35$ and $67.78 \pm 3.32$ and $75.56 \pm 1.75$ and $80 \pm 2.34 \mathrm{mmHg}$ ) in the trial group decreased significantly $(\mathbf{p}<0.05)$ compared to the control group, after treatment. There were significant $(p<0,05)$ differences of serum calcium in treatment between control group $(8.9 \pm 0,05$; $9.3 \pm 0,09$ vs $9.08 \pm 0.06 ; 9.56 \pm 0,14 \mathrm{mg} / \mathrm{dl})$ and significant $(P<0.05)$ correlation was found between serum calcium and systolic $(\mathrm{r}=0.68, \mathrm{t}=-0.38, \mathrm{p}=0.04 \mathrm{mmHg})$ and diastolic blood pressure $(r=0.76, t=-2,24, p=0.01)$ after treatment. It can be concluded that goat's milk lowers blood pressure and prevent hypertension in sedentary women.
\end{abstract}

Keywords - blood pressure, calcium, goat milk, exercise, hypertension, untrained

\section{INTRODUCTION}

Hypertension is the most common condition seen in primary care and leads to myocardial infarction, stroke, renal failure, and death if not detected early and treated appropriately [1]. Hypertension remains one of the most important preventable contributors to disease and death. Hypertension is defined as a Systolic blood pressure equal or greater than to 140 $\mathrm{mmHg}$ or diastolic blood pressure equal or greater than to $90 \mathrm{mmHg}$, or currently taking medication to lower high blood pressure [1], [2]. Hypertension affects more than 50 million Americans, and can lead to the development of cardiovascular disease, stroke, and renal failure. [3], [4], [5] According to World Health Organization, 2014, Incident of high blood pressure in Indonesia about $29.1 \%$ (males) and 26,6 (females), a total 27.8\% Indonesian people.
[6] Incident of hypertension in Aceh, Indonesia about 19,5-46,1\% (average 30,2\%) [7].

The cause of hypertension is multifactor, including lifestyle: food consumption patterns. Habits of the people of Aceh since a long time is consumed goat meat or in the Achenese language called "Kare kambing or Kuah Beulangong". The myth that has long been developing in Indonesia, including Acehnese are eating goat meat will increase blood pressure resulting in hypertension and would be the same if we consume goat milk. But this has not been vetted. However, some experts actually found the opposite, consume goat milk can actually reduce the blood pressure [8]. High calcium content in goat milk is allegedly one of the factors that influence the blood pressure [9], [10], [11]. On this basis that we are interested to study the effect of goat milk consumption on blood pressure.

Non-pharmacological approach such as dietary modification likes goat milk plays an important role in controlling blood pressure [2], [4]. Dietary goat milk regularly may be could reduce blood pressure in normotensive patient. Goat milk components such as sodium, potassium, calcium, and magnesium have been studied substantially in the past decades [2], [4]. Low levels of calcium, either due to dietary deficiencies or altered calcium metabolism, have been linked by several epidemiological and laboratory studies to higher blood pressure, or hypertension [12], [13]. Disturbances in calcium metabolism that cause calcium deficiency have been linked to abnormal blood pressure control. [12] This study aimed to analyse the influence of goat milk on blood pressure reduction that goat milk can be used as an antihypertensive. 


\section{METHODS}

\section{A. Research Design}

This research was randomized clinical trial (randomized double-blind design). Subjects are sedentary women with normotensive patient. A total of 18 subjects in the age group of 18-19 years participated in the study. They were divided into two groups: (1) control group (without given goat milk) and (2) trial group (given goat milk). Selection of subject research conducted by simple random sampling using a lottery system.

\section{B. Treatment procedures, examination of Serum Calcium Levels and Blood Pressure}

The treatment was fresh goat's milk. Before it was given, the milk is checked in the lab. Goat milk dose given is $1 \times 250 \mathrm{ml} /$ day, given in the morning at 8:00 am to 9:00 pm, for 110 days. Before collecting the blood sample, subjects were fasted for 10-12 hours from 8:00 pm-20.00 pm. The collection of a blood sample performed in the morning (07:00 to 8:30 pm). Examination of serum calcium was conducted using O-cresolphthalein complexone, using a photometer 4010. Normal serum calcium levels are 8.6 to $10.3 \mathrm{mg} / \mathrm{dl}$. Measurement of blood pressure are conducted using mercury sphygmomanometer. Examination of blood pressure (systolic and diastolic) and serum calcium levels before and after administration of goat's milk.

\section{Data analysis and Ethical Clearance}

Analysis of the data used: test of homogeneity of variance according to Levene's test ( $p>0.05)$, test of normality of Kolmogorov-Smirnov ( $p>0.05$ ), paired t-test $(\mathrm{p}<0.05)$ and Pearson correlation test $(\mathrm{p}<0.05)$.
This research has been conducted based on the ethical considerations of the Medical Research Ethics Committee at the Faculty of Medicine, University of Syiah Kuala in Banda Aceh, according to the letter number 304 / KE / FK / 2015.

\section{RESULTS AND DISCUSSION}

\section{A. Characteristics of research subjects}

Table 1 shows that the characteristics of the research subjects such as: age (years), weight $(\mathrm{kg})$, height $(\mathrm{cm})$, body mass index $(\mathrm{BMI}=\mathrm{kg} / \mathrm{m} 2)$ between trial and control group was not significantly different ( $\mathrm{p}>0.05)$.

\section{B. Homogeneity test}

The results of the test homogeneity of variance using Levene-test ( $p>0.05)$ on systolic and diastolic blood pressure and serum calcium levels indicate that the data variance is homogeneous Table 2.

\section{Normality test}

The results of the normality test KolmogorofSmirnov $(p>0.05)$ on blood pressure and serum calcium levels indicate that the data has a normal distribution, as listed in Table 3.

\section{Differences Effect of Goat Milk on Blood Pressure and Serum Calcium Levels}

Comparison of the average and paired t-test of systolic and diastolic blood pressure and serum calcium levels before and after administration of goat milk between trial and control groups, as shown in Table 4.

\begin{tabular}{|c|c|c|c|c|c|c|}
\hline \multirow{2}{*}{ Variables } & \multicolumn{2}{|c|}{ Trial group } & \multicolumn{2}{c|}{ Control group } & \multirow{2}{*}{ t value } & \multirow{2}{*}{ p-value } \\
\cline { 2 - 5 } & Mean & SD & Mean & SD & & 0.50 \\
\hline Age $($ years) & 18.77 & 0.44 & 18.66 & 0.50 & 0.50 & 0.21 \\
\hline Weight $(\mathrm{kg})$ & 51.77 & 8.60 & 47.72 & 3.91 & 1.28 & 0.50 \\
\hline Height $(\mathrm{cm} 2)$ & 154.33 & 2.69 & 153.56 & 2.12 & 0.68 & 0.30 \\
\hline BMI $(\mathrm{kg} / \mathrm{m} 2)$ & 21.80 & 3.98 & 20.25 & 1.77 & 1.06 & \\
\hline
\end{tabular}


TABLE II

TEST HOMOGENEITY OF VARIANS FOR SYSTOLIC, DIASTOLIC AND SERUM CALCIUM BETWEEN TRIAL AND CONTROL

\begin{tabular}{|c|c|c|c|}
\hline Variables & Groups & Levene statistic-F & p- value \\
\hline \multirow{2}{*}{ Systolic $(\mathrm{mmHg})$} & Trial & 0.37 & 0.67 \\
\cline { 2 - 4 } & Control & 0.18 & 0.78 \\
\hline Diastolic $(\mathrm{mmHg})$ & $\begin{array}{c}\text { Trial } \\
\text { Control }\end{array}$ & 0.07 & 0.55 \\
\hline \multirow{2}{*}{ Calcium $(\mathrm{mg} / \mathrm{dl})$} & Trial & Control & 0.07 \\
\cline { 2 - 4 }
\end{tabular}

TABLE III

TEST OF NORMALITY FOR SYSTOLIC, DIASTOLIC AND SERUM CALCIUM BETWEEN TRIAL AND CONTROL

\begin{tabular}{|c|c|c|c|c|}
\hline \multirow{2}{*}{ Variables } & \multicolumn{2}{|c|}{ Trial group } & \multicolumn{2}{c|}{ Control group } \\
\cline { 2 - 5 } & Kolmogorof-Smirnov Z & p- value & Kolmogorof-Smirnov Z & p-value \\
\hline Systolic $(\mathrm{mmHg})$ & 0.27 & 0.48 & 0.34 & 0.30 \\
\hline Diastolic $(\mathrm{mmHg})$ & 0.27 & 0.44 & 0.35 & 0.40 \\
\hline Calcium $(\mathrm{mg} / \mathrm{dl})$ & 0.28 & 0.16 & 0.33 & 0.10 \\
\hline
\end{tabular}

TABLE IV

PAIRED T TEST FOR SYSTOLIC, DIASTOLIC AND CALCIUM SERUM BETWEEN TRIAL AND CONTROL

\begin{tabular}{|c|c|c|c|c|c|c|}
\hline Variables & Groups & Data & $\mathbf{N}$ & Mean \pm SD & t test & p- value \\
\hline \multirow{2}{*}{ Systolic $(\mathrm{mmHg})$} & \multirow{2}{*}{ Trial } & Pretest & 9 & $101.11 \pm 9.27$ & \multirow{2}{*}{-3.5} & \multirow{2}{*}{$0.00 *$} \\
\hline & & Posttest & 9 & $93.33 \pm 5.00$ & & \\
\hline & \multirow{2}{*}{ Control } & Pretest & 9 & $112.22 \pm 9.71$ & \multirow{2}{*}{-1.51} & \multirow{2}{*}{0.16} \\
\hline & & Posttest & 9 & $110.00 \pm 8.66$ & & \\
\hline \multirow{4}{*}{$\begin{array}{l}\text { Diastolic } \\
(\mathrm{mmHg})\end{array}$} & \multirow{2}{*}{ Trial } & Pretest & 9 & $70.00 \pm 7.07$ & \multirow{2}{*}{0.68} & \multirow{2}{*}{0.51} \\
\hline & & Posttest & 9 & $67.78 \pm 9.71$ & & \\
\hline & \multirow[b]{2}{*}{ Control } & Pretest & 9 & $75.55 \pm 5.27$ & \multirow{2}{*}{2.53} & \multirow{2}{*}{$0.03 *$} \\
\hline & & Posttest & 9 & $80.00 \pm 0.00$ & & \\
\hline \multirow{4}{*}{ Calcium (mg/dl) } & \multirow{2}{*}{ Trial } & Pretest & 9 & $8.90 \pm 0.16$ & \multirow{2}{*}{4.66} & \multirow{2}{*}{$0.00 *$} \\
\hline & & Posttest & 9 & $9.36 \pm 0.29$ & & \\
\hline & \multirow{2}{*}{ Control } & Pretest & 9 & $9.08 \pm 0.20$ & \multirow{2}{*}{3.87} & \multirow{2}{*}{0.16} \\
\hline & & Posttest & 9 & $9.56 \pm 0.14$ & & \\
\hline
\end{tabular}

TABLE V

PEARSON CORRELATION TEST FOR CORRELATION BETWEEN SYSTOLIC AND CALCIUM SERUM BETWEEN TRIAL AND CONTROL GROUPS

\begin{tabular}{|c|c|c|c|}
\hline Groups & $\mathbf{R}$ & $\mathbf{T}$ & p- value \\
\hline Trial & 0.76 & 3.14 & 0.04 \\
\hline Control & 0.06 & 2.30 & 0.48 \\
\hline
\end{tabular}

Results of paired t test ( $\mathrm{p}<0.05)$ showed that the average value of systolic blood pressure after treatment goat milk in the trial group showed a

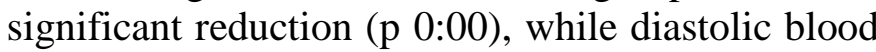

pressure decreased but not significant statistically $(p=0.51)$. In contrast, the average diastolic value in the control group increased after the administration of goat milk $(p=0: 03)$. The average value of the 
serum calcium level after the administration of the goat milk in the trial group increased significantly ( $\mathrm{p}<0.05$ ); while the average of serum calcium levels in the control group did not increase ( $p$ $<0.05$ ), as shown in Table 4 . The results of this study indicate that: giving goat milk can lower systolic blood pressure $(p=0.00)$ and stimulate increased serum calcium levels $(\mathrm{p}=0.00)$.

The correlation between a decrease of systolic blood pressure with an increase of serum calcium levels in trial group performed a Pearson correlation test (r), $\mathrm{p}<0.05$. The results of Pearson correlation test $(\mathrm{r}), \mathrm{p}<0.05$ indicates a strong correlation significance $(\mathrm{p}=0.04)$ between systolic blood pressure and serum calcium. That is a decrease in systolic blood pressure was associated with increased serum calcium levels in sedentary women. The results of Pearson correlation test ( $r$ ) can be seen in Table 5.

The results of this study showed that the consumption of goat milk regularly can lower systolic blood pressure in sedentary women with normotensive and a decrease of systolic blood pressure was associated with increased serum calcium levels. Calcium plays a role in blood pressure (BP) regulation, but the importance of supplemental calcium intake for the prevention of hypertension is still debated [14]. Dietary deficiencies or altered calcium metabolism can result in low serum calcium levels. Disturbances in calcium metabolism include increased urinary calcium excretion and abundance of calciumregulating hormones such as parathyroid hormone and calcitriol. These hormones cause decreases in bone mineral content and increase intracellular calcium in vascular smooth muscle. Increased $[\mathrm{Ca} 2+]$ produces contraction and therefore vasoconstriction. Low calcium levels and elevated PTH and calcitriol may also affect blood pressure control by the central and peripheral nervous systems by stimulating the release of norepinephrine (a potent vasoconstrictor) and increasing its post-synaptic effect [15]. Calcium supplementation (1g/day) may significantly reduce systolic BP by $1.9 \mathrm{mmHg}$ and diastolic BP by 1.0 $\mathrm{mmHg}$. The BP effect tended to be more pronounced in populations with a habitually low calcium intake $(2.6 / 1.3 \mathrm{mmHg})$. Blood pressure showed no further decrease when calcium doses exceeded 1 g/day. [14] Goat milk contains protein, lipid, carbohydrate, vitamin and mineral [11]. Goat milk is reported to have higher content of Potassium, Calcium, chloride, Phosphorus, Selenium, Zinc and Copper than cow milk. [16], [17]. Administration of calcium salts have had the effect of reducing hypertension in the spontaneously hypertensive rat and also models of salt-sensitive hypertension rat [3], [13], [14], [15]. Effects of dietary calcium in human have varied from study to study. Increased calcium results in lower blood pressure. Increases in calcium intake produced a mild antihypertensive response, with the average decrease of 4-7 $\mathrm{mmHg}$ systolic and 2-4 $\mathrm{mmHg}$ diastolic [12]. Increased calcium intake likes goat milk reduces risk of hypertension.

Goat milk has a distinct antihypertension impact and its specific composition may result in the decreased blood pressure [11]. An in-vitro study has shown that human who had been consumption goat milk were triggered to release nitric oxide (NO). Goat milk was able to active NO release from blood cells. NO is a vasodilator substance and exerts a cardio-protective and anti-atherogenic affect [18]. Goat milk also contain casein. Casein derived from goat milk yogurt showed blood pressure lowering effect and caused major changes of the SBP in the treated DOCA-salt hypertensive rats for more than $50 \mathrm{mmHg}$ [19].

\section{CONCLUSIONS}

It is concluded that: (1) Consumption of goat milk regularly can lower systolic blood pressure in sedentary women with normotensive,

Consumption of goat milk regularly may increase serum calcium levels in sedentary women with normotensive, (3) The decrease in blood pressure due to consumption of goat milk regularly associated with increased serum calcium levels in sedentary women with normotensive.

\section{ACKNOWLEDGMENT}

We acknowledge the ministry of research and technology higher education Republic of Indonesia for funding this project and Institute for Research and Community Service (LPPM) of Syiah Kuala University Banda Aceh for overseeing the project 
and administering the contract. Thank to Clinical Laboratory of Prodia Banda Aceh for the collaboration and supported this research.

\section{CONFLICT OF INTEREST}

This article does not have a conflict of interest with the various parties and this article is an original article that has not been published. None of the authors had an existing or potential conflict of interest with this article.

\section{REFERENCES}

[1] James, PA, Oparil, S; Carter BL, Cushman, WC, et al. (2014) Evidence-Based Guideline for the Management of High Blood Pressure in Adults Report From the Panel Members Appointed to the Eighth Joint National Committee (JNC 8). JAMA 311(5):507-520.

[2] Nguyen H, Odelola OA, Rangaswami J and Amanullah A. (2013) A Review of Nutritional Factors in Hypertension Management. International Journal of Hypertension 2013: 1-12

[3] Morris, CD and Reusser ME. (1995) Calcium Intake and Blood Pressure: Epidemiology Revisited. Seminars in Nephrology 15(6): 4905.

[4] Reusser, ME and McCarron DA. (1994) Micronutrient Effects on Blood Pressure Regulation. Nutrition Reviews 52(11): 367-75.

[5] Yoon SS, Fryar CD, and Carroll MD. (2015) Hypertension Prevalence and Control Among Adults: United States, 2011-2014. NCHS Data Brief No. 220. November 2015. 1-8

[6] WHO, 2014. Noncommunicable Diseases (NCD) Country Profiles. at http://www.who.int/nmh/countries/idn en.pdf

[7] Riset kesehatan dasar (RISKESDAS) Provinsi Nanggroe Aceh Darussalam tahun 2007. (2009) Badan penelitian dan pengembangan Kesehatan Departemen Kesehatan Republik Indonesia
[8] Sunagawa K, Kishi T, Nagai A, Matsumura, Nagamine I and Uechi S. (2014) Goat Meat Does Not Cause Increased Blood Pressure. Asian Australas. J. Anim. Sci 27(1):101-114

[9] Zamberlin S, Antunac N, Havranek J, and Dubravka Samaržij. (2012) Mineral elements in milk and dairy products. Mljekarstvo. 62(2): 111125

[10] Johansson S. (2011) Goat Milk: Nutrition and health aspects. at http://dalsspira.se/wp-content/upLoads/goatmilk-nutrition-health aspects.pdf: pp 1-24.

[11] Zenebe T, Ahmed N, Kabeta T and Kebede G. (2014) Review on Medicinal and Nutritional Values of Goat Milk. Academic Journal of Nutrition. 3(3): 30-39.

[12] McCarron, D.A. (2003) Calcium. Symposium Notes: Nonpharmacologic Management of Hypertension. National Kidney Foundation, 2003, pp 34-38.

[13] Morris, CD and Reusser ME. (1995) Calcium Intake and Blood Pressure: Epidemiology Revisited. Seminars in Nephrology, 15(6): 490-5.

[14] van Mierlo LAJ, Arends LR, Streppel MT, Zeegers MPA, Kok FJ, Grobbee DE, and Geleijnse JM. (2006) Blood pressure response to calcium supplementation: a eta-analysis of randomized controlled trials. Journal of Human Hypertension 20:571-580

[15] Martinez and Christina. (1998) Los Angeles. Calcium and $\begin{array}{lll}\text { Hypertension. Nutrition } & \text { Bytes, } 2): 1-4 \quad \text { at }\end{array}$ http://escholarship.org/uc/item/68b658ss

[16] Krstanovic, VV. Slacanac, R, Bozanic, J, Hardi, J, Rezessyne and Lucan M. (2010) Nutritional and therapeutic value of fermented caprine milk. International Journal of Dairy Technology 63:171-189.

[17] Lopez-Aliaga, IMJ, Alferez, MT, Nestares, PB, Barrionuevo RM and Campos MS. (2005) Goat milk feeding causes an increase in biliary secretion of cholesterol and a decrease in plasma cholesterol levels in rats. J Dairy Sci., 88:102-141.

[18] Park, YW, Juarez M, Ramos M and Haenlein GFW. (2011) Physicochemical characteristics of goat and sheep milk 15: 223-250.

[19] Padaga MC, Aulanni'am, Sujuti H and Widodo. (2015) Blood Pressure Lowering Effect and Antioxidative Activity of Casein Derived from Goat Milk Yogurt in DOCA-salt Hypertensive Rats. International Journal of PharmTech Research. 8(6):322-330. 